Supporting information

\title{
Critical Role of Redox Mediator in Suppressing Charging Instabilities of Lithium-Oxygen Batteries
}

\section{Zhuojian Liang and Yi-Chun Lu}

Electrochemical Energy and Interfaces Laboratory, Department of Mechanical and Automation Engineering, The Chinese University of Hong Kong, Hong Kong SAR, China

Email: yichunlu@mae.cuhk.edu.hk

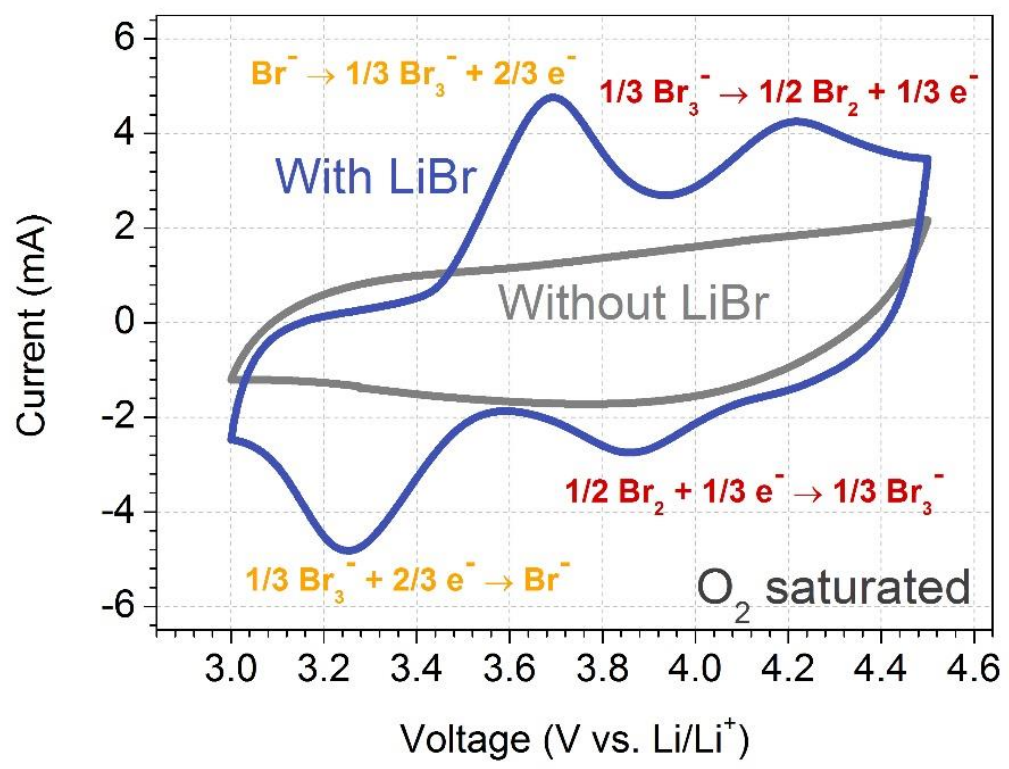

Figure S1. Cyclic Voltammetry of $\mathrm{LiBr}$ at $25 \mathrm{mV} / \mathrm{s}$ on the Ketjenblack electrode, in $50 \mathrm{mM} \mathrm{LiBr-1}$ M LiTFSI in diglyme electrolyte, with a piece of Li foil acting as both the anode and the reference electrode. 


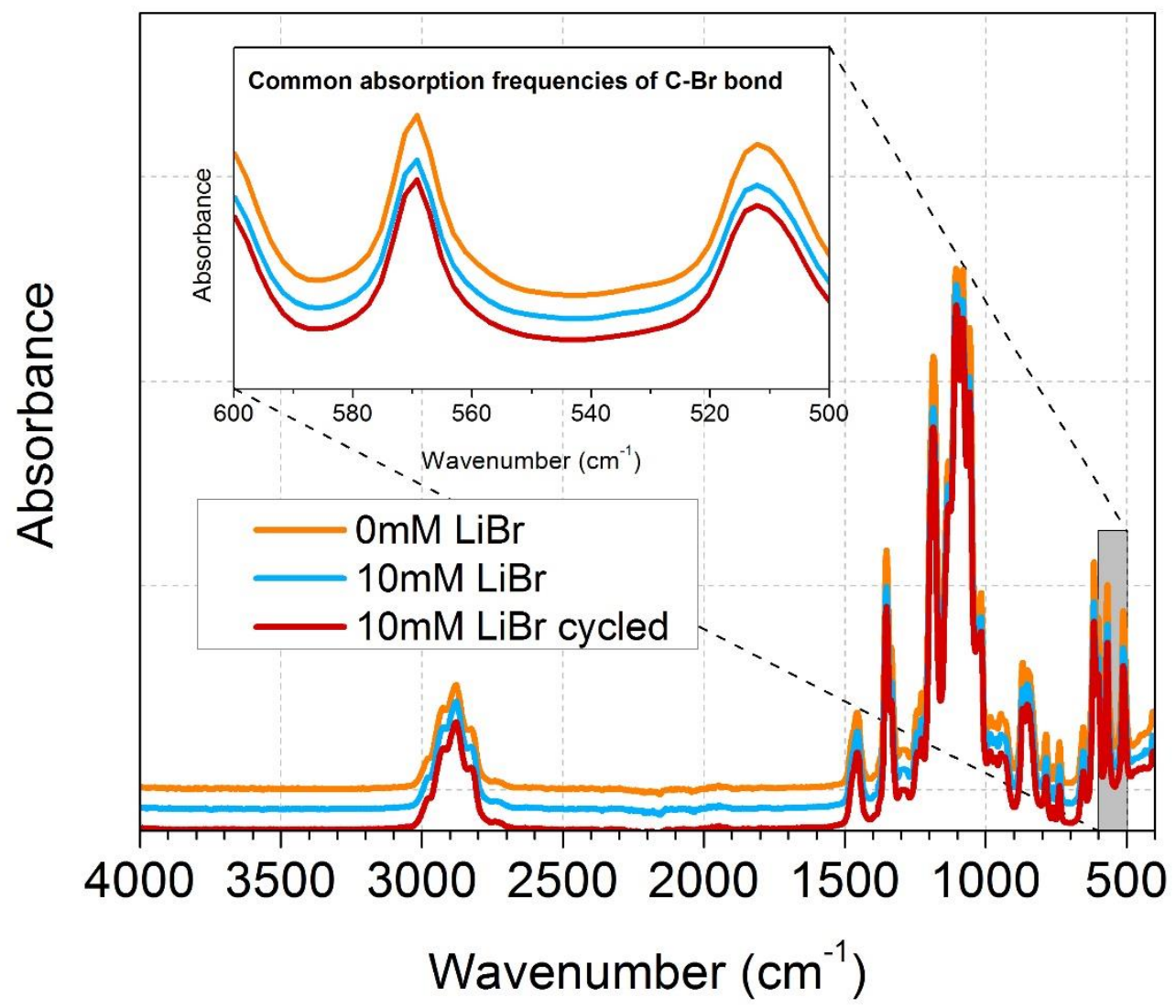

Figure S2. FTIR analysis results of 1 M LiTFSI in diglyme, $10 \mathrm{mM} \mathrm{LiBr} \mathrm{-} \mathrm{1M} \mathrm{LiTFSI} \mathrm{in} \mathrm{diglyme} \mathrm{and} 10$ $\mathrm{mM} \mathrm{LiBr}-1 \mathrm{M} \mathrm{LiTFSI}$ in diglyme after cycling between $3.0-4.5 \mathrm{~V} \mathrm{vs.} \mathrm{Li}^{-\mathrm{Li}^{+}}$at $1 \mathrm{mV} / \mathrm{s}$.

Figure S2 and Figure $S_{3}$ show the results of Fourier transform infrared spectroscopy (FTIR) and electrospray ionization mass spectrometry (ESI-MS) of the pristine electrolyte (1M LiTFSI in diglyme), as prepared $10 \mathrm{mM} \mathrm{LiBr}-1 \mathrm{M} \mathrm{LiTFSI}$ in diglyme and $10 \mathrm{mM} \mathrm{LiBr}-1 \mathrm{M}$ LiTFSI in diglyme after cycling between 3.0 - 4.5 V vs. $\mathrm{Li} / \mathrm{Li}^{+}$(at $1 \mathrm{mV} / \mathrm{s}$ ). No difference can be identified by FTIR in the region of $\mathrm{C}-\mathrm{Br}$ bond for all samples and no byproducts arising from reaction between the $\mathrm{Br}-$ containing species and the diglyme such as $\mathrm{C}_{6} \mathrm{H}_{13} \mathrm{O}_{3} \mathrm{Br}\left(\mathrm{m} / \mathrm{z}=\mathbf{2 2 0 . 0 1}\right.$ for $\left.\left[\mathrm{C}_{6} \mathrm{H}_{13} \mathrm{O}_{3} \mathrm{Br}+\mathrm{Li}\right]^{+}\right)$can be identified by ESI-MS for all three samples. The peaks at $\mathrm{m} / \mathrm{z}=141,157$ and 275 are attributed to $\left[\mathrm{C}_{6} \mathrm{H}_{14} \mathrm{O}_{3}+\mathrm{Li}\right]^{+},\left[\mathrm{C}_{6} \mathrm{H}_{14} \mathrm{O}_{5}+\mathrm{Li}\right]^{+}\left(\mathrm{C}_{6} \mathrm{H}_{14} \mathrm{O}_{5}\right.$ is diglyme peroxide, which is the autoxidation product of diglyme) and $\left[{ }_{2} \mathrm{C}_{6} \mathrm{H}_{14} \mathrm{O}_{3}+\mathrm{Li}\right]^{+}$, respectively. 


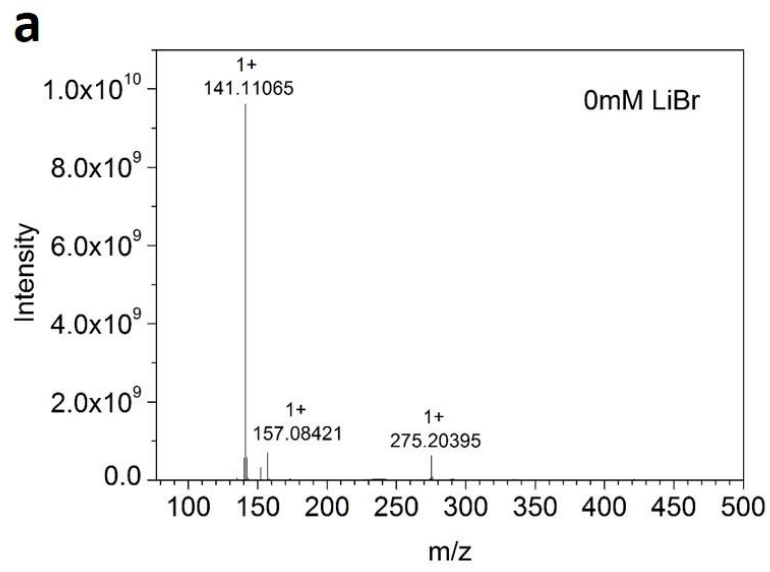

b
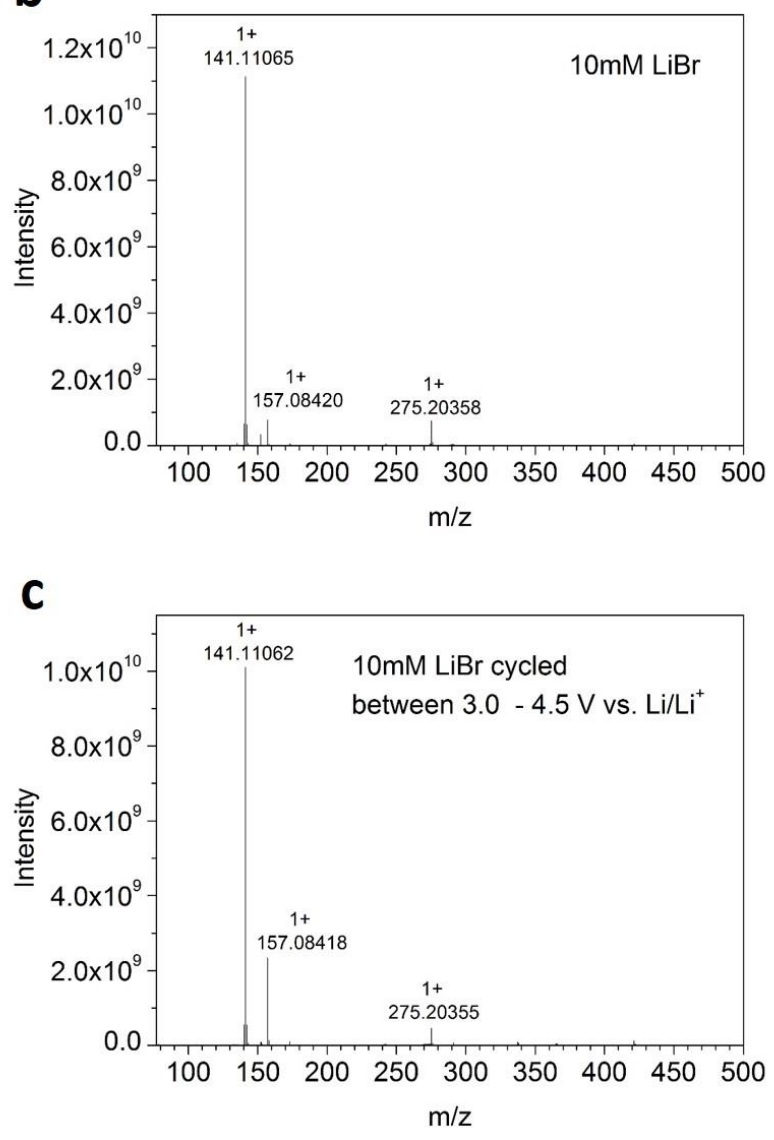

Figure S3. ESI-MS analysis results of: (a) $1 \mathrm{M}$ LiTFSI in diglyme; (b) $10 \mathrm{mM} \mathrm{LiBr}-1 \mathrm{M}$ LiTFSI in diglyme and (c) $10 \mathrm{mM} \mathrm{LiBr}-1 \mathrm{M}$ LiTFSI in diglyme after cycling between $3.0-4.5 \mathrm{~V} \mathrm{vs}$. Li/ $/ \mathrm{Li}^{+}$. 


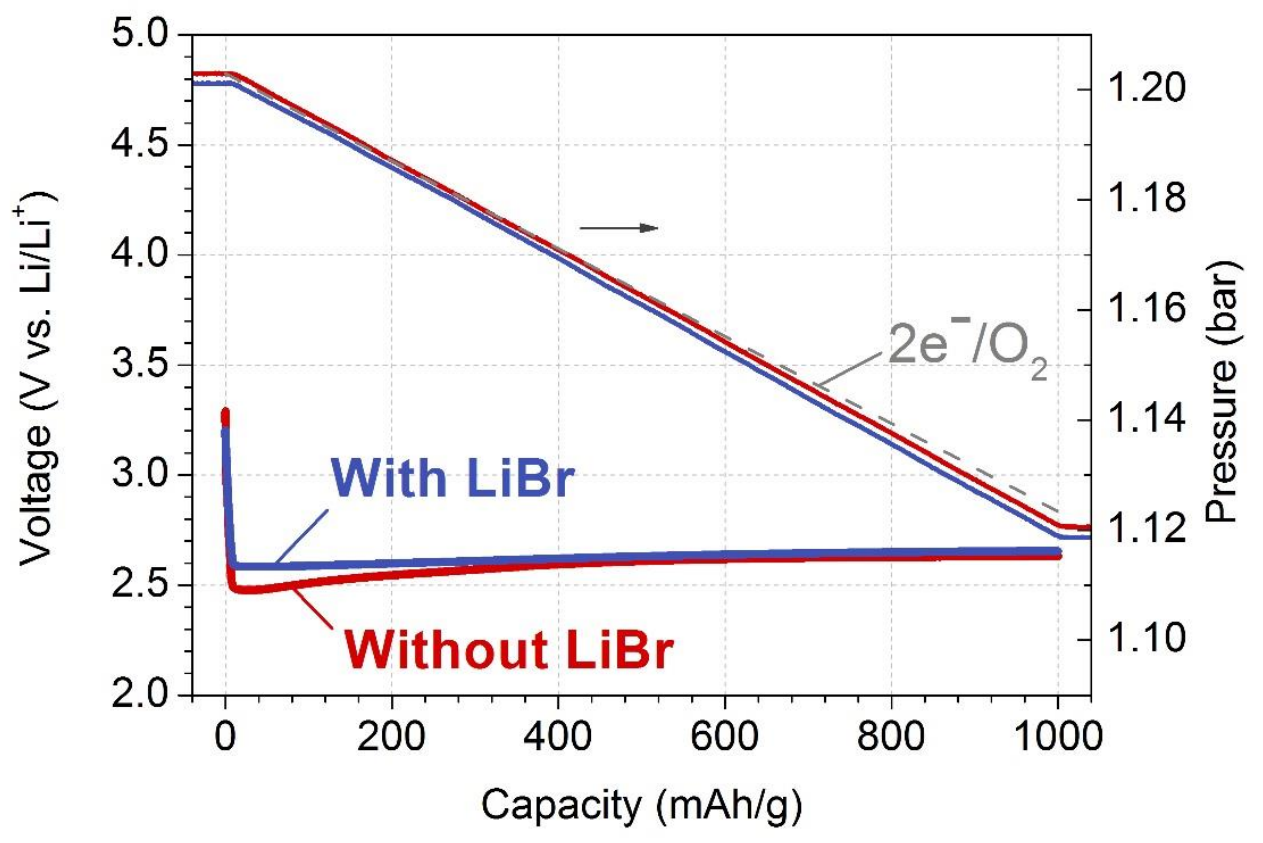

Figure $\mathrm{S}_{4}$. Oxygen pressure reduction monitored by pressure transducer during discharge with and without $10 \mathrm{mM} \mathrm{LiBr}$ at $1000 \mathrm{~mA} / \mathrm{g}$ to $1000 \mathrm{mAh} / \mathrm{g}$.

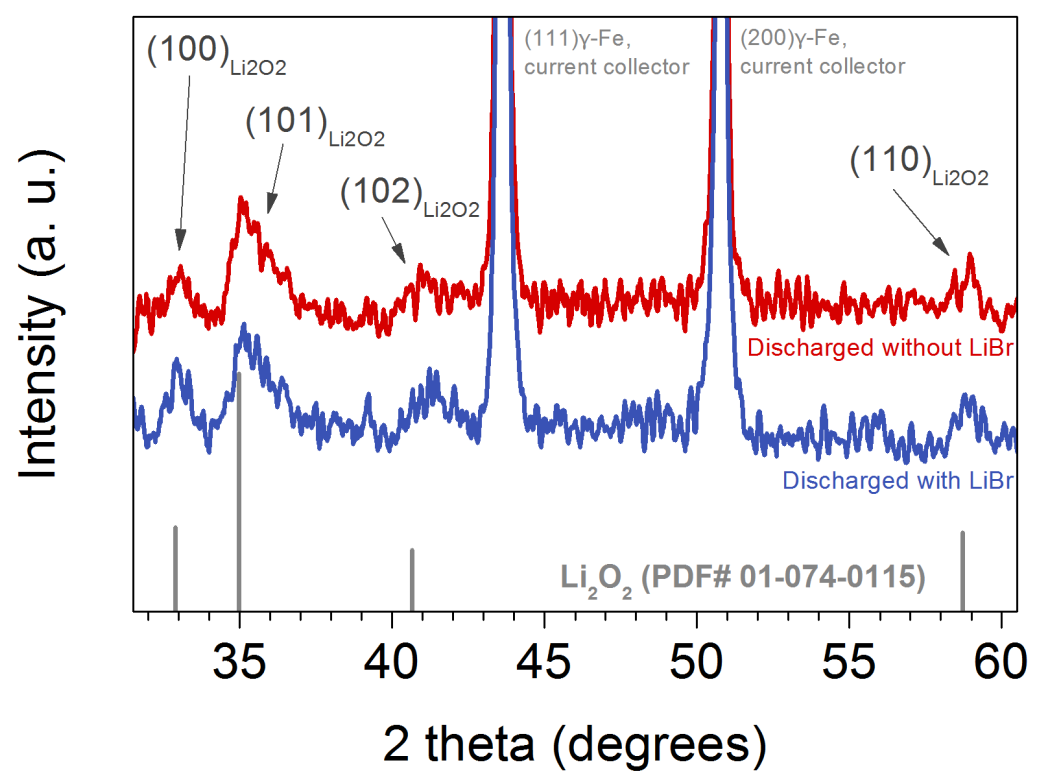

Figure $\mathrm{S}_{5}$. X-ray diffraction patterns of $\mathrm{Li}_{-} \mathrm{O}_{2}$ positive electrodes after discharge with and without $10 \mathrm{mM} \mathrm{LiBr}$ at $1000 \mathrm{~mA} / \mathrm{g}$ to $1000 \mathrm{mAh} / \mathrm{g}$. 


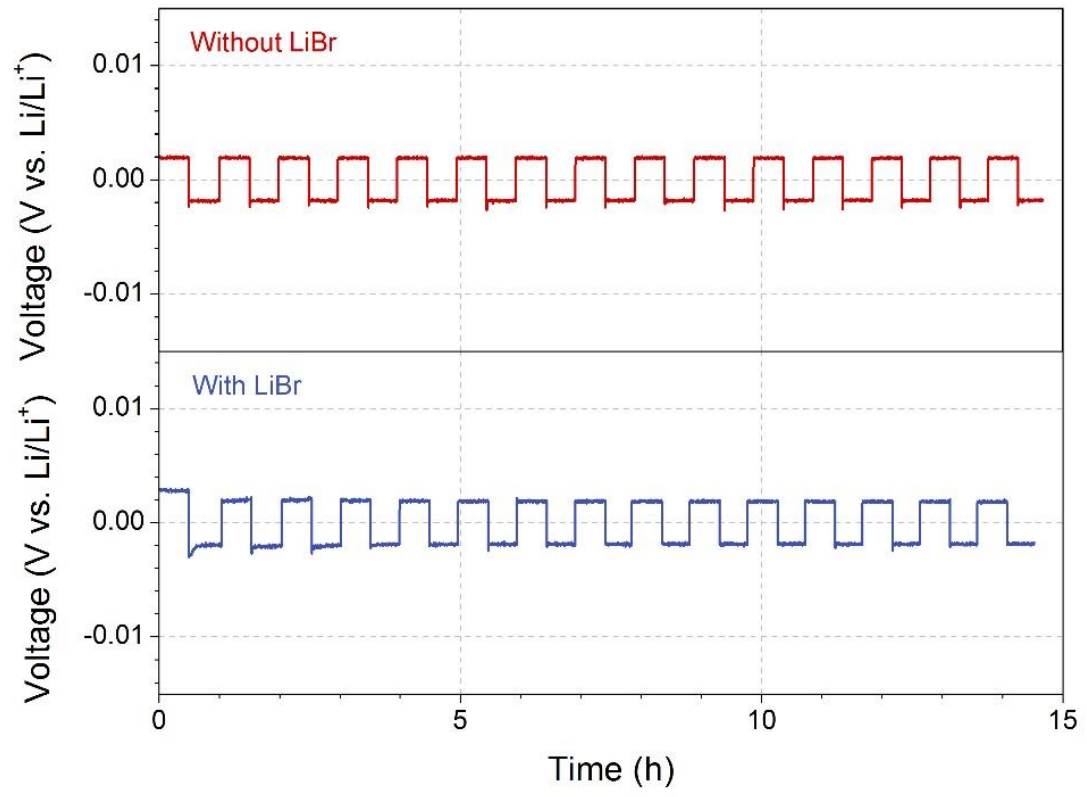

Figure S6. Voltage profiles of the lithium anode of $\mathrm{Li}^{-} \mathrm{O}_{2}$ cells upon cycling at $1000 \mathrm{~mA} / \mathrm{g}(=800$ $\mathrm{uA}$ absolute current) to $1000 \mathrm{mAh} / \mathrm{g}$ with and without $10 \mathrm{mM} \mathrm{LiBr}$. A third electric connection point was incorporated at the center of the anode side of the original cell, on which a piece of $\Phi_{3}$ $\mathrm{mm} \mathrm{Li}$ was added as an independent reference electrode. 

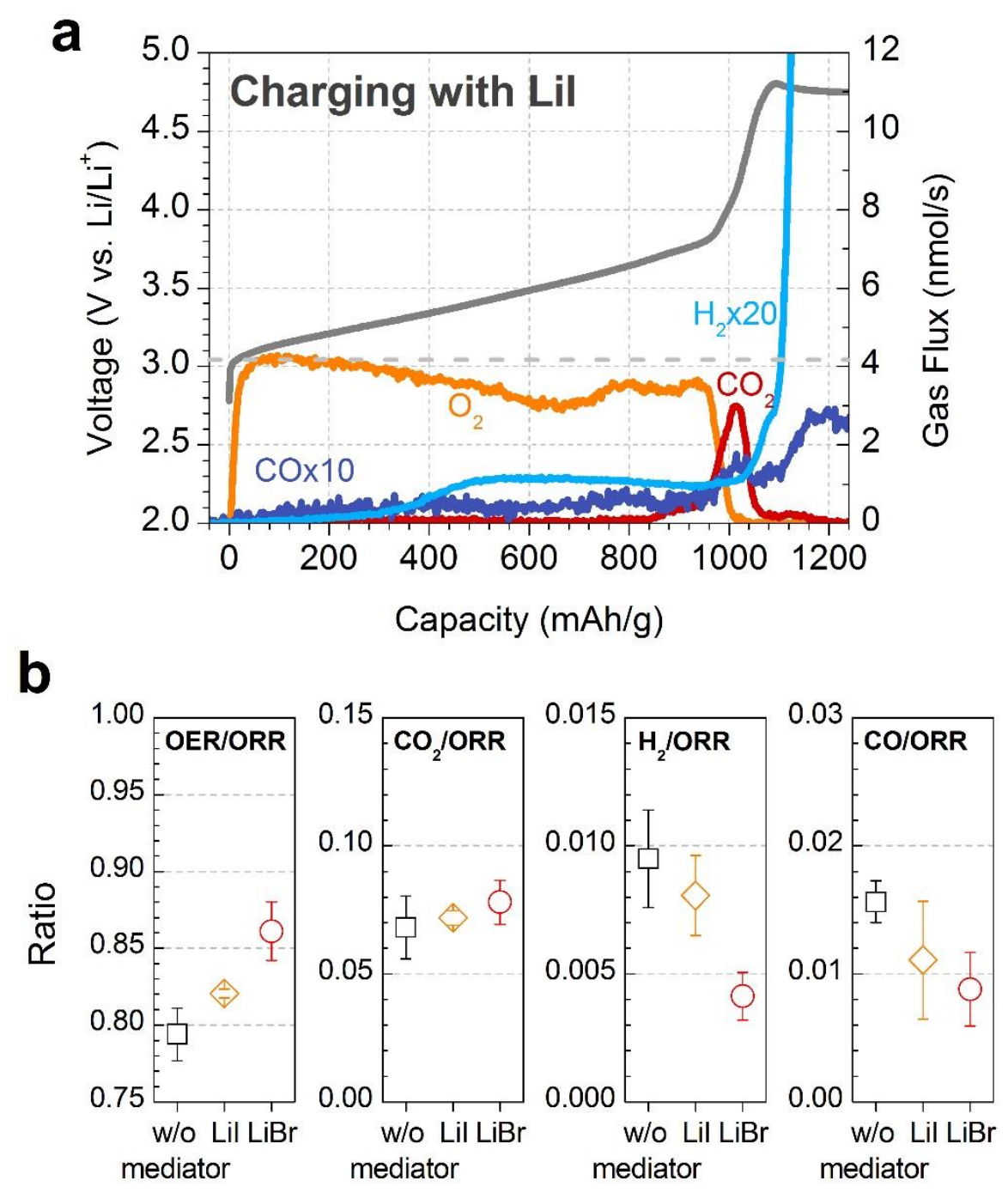

Figure $\mathrm{S}_{7}$. Voltage and gas evolution profiles of the first charge with $10 \mathrm{mM}$ LiI after discharged to $1000 \mathrm{mAh} / \mathrm{g}$ at $1000 \mathrm{~mA} / \mathrm{g}$. Panel (c) shows statistics based on at least 3 replications. 


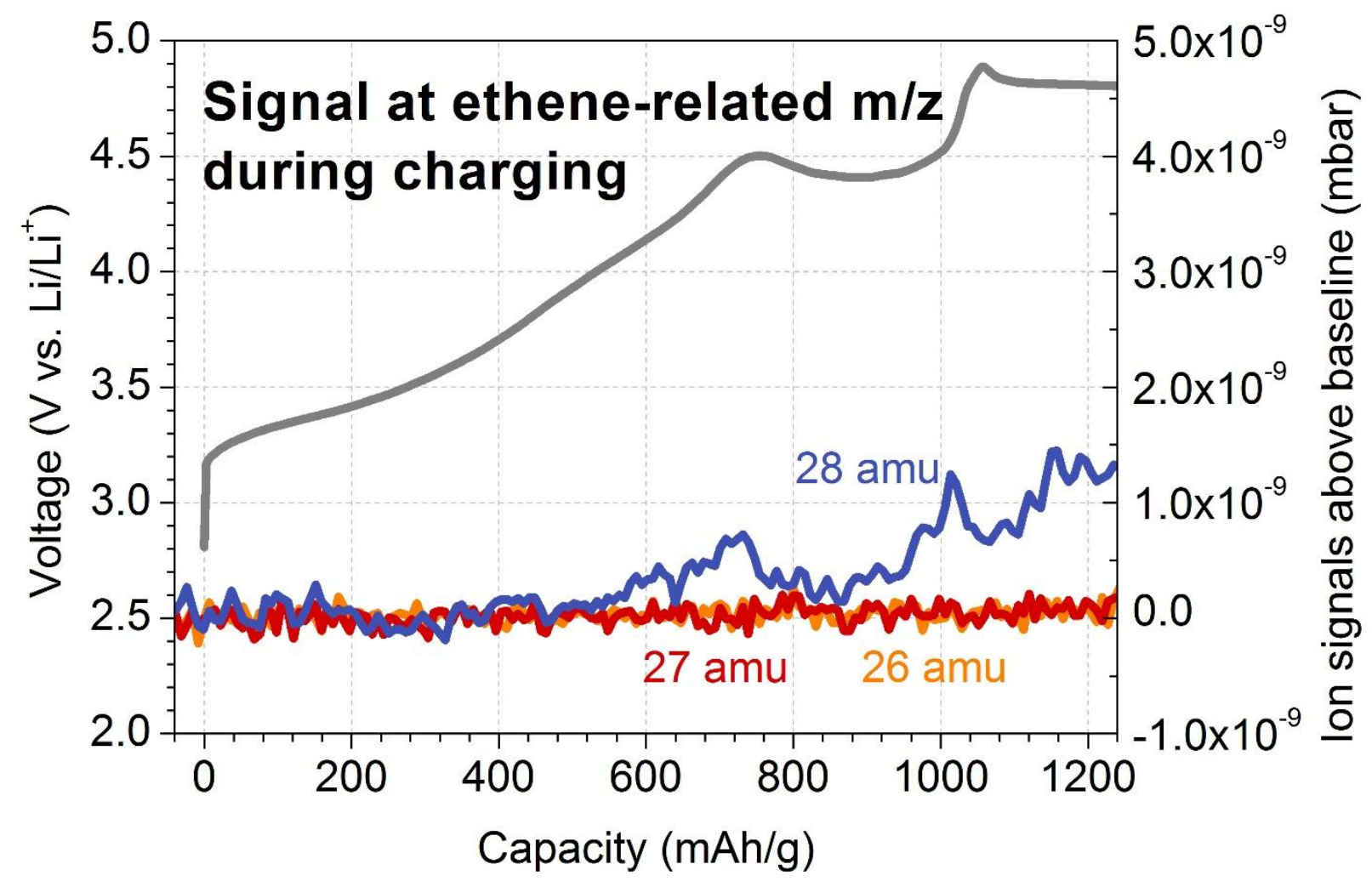

Figure S8. Mass spectrometer signals at 26, 27 and 28 amu during charging. 


\section{(a) Electrolyte volume used in this study (60 ul on both sides)}

No liquid communication between cathode and anode
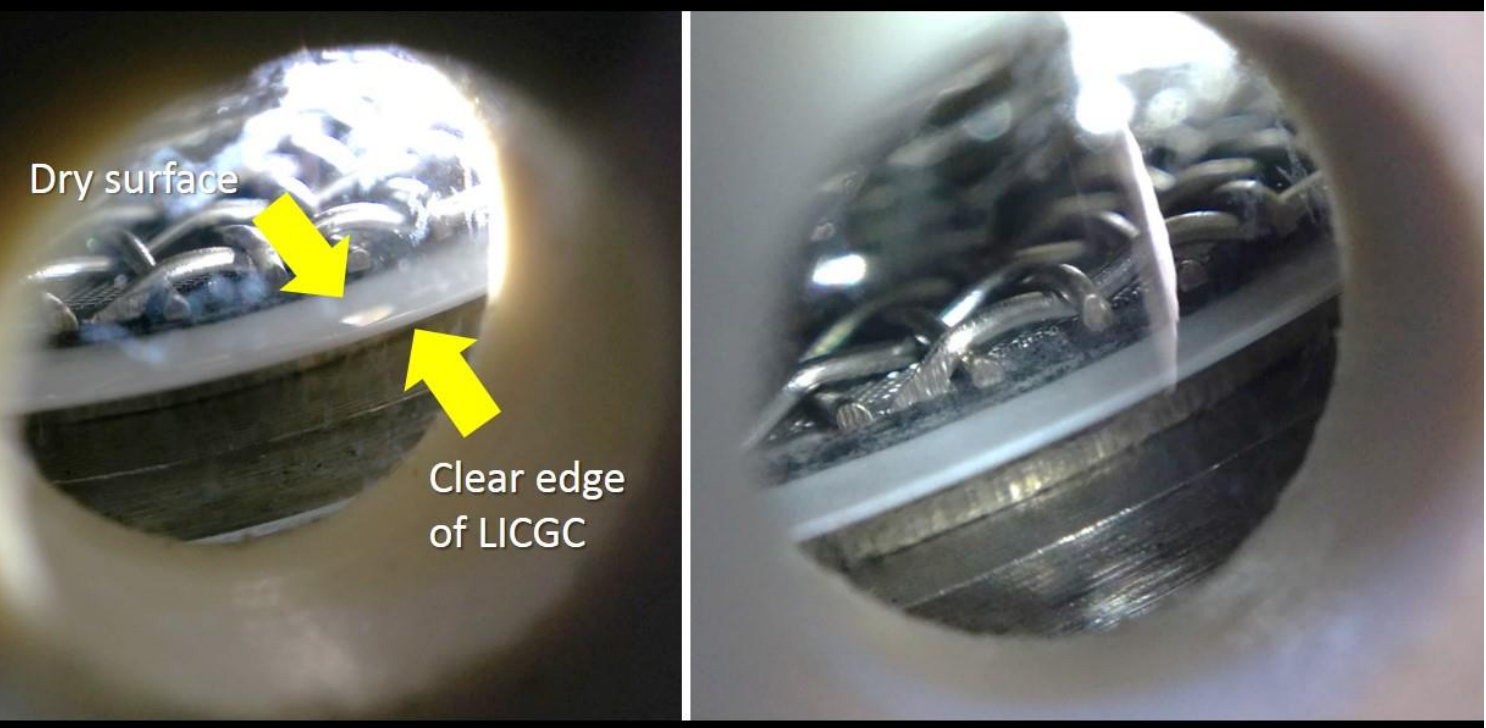

(b) Excess electrolyte volume for comparison and contrast Direct liquid communication between cathode and anode

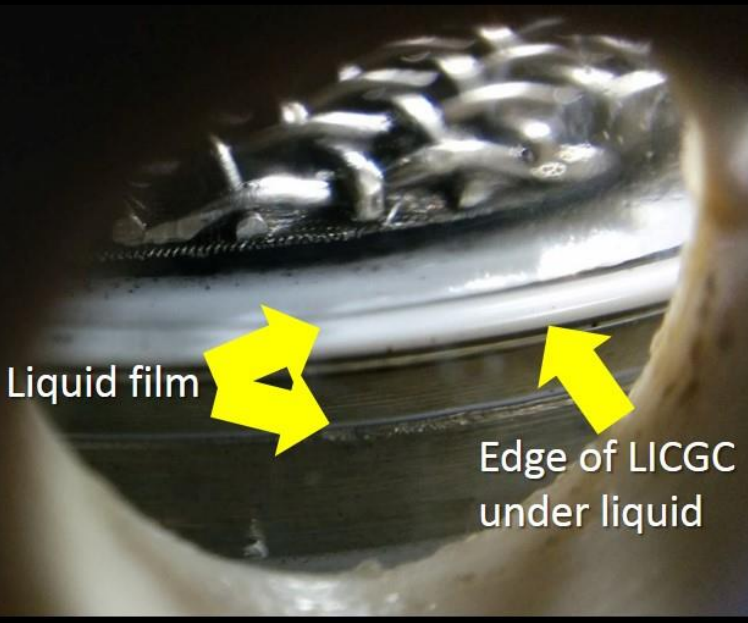

100ul on both sides

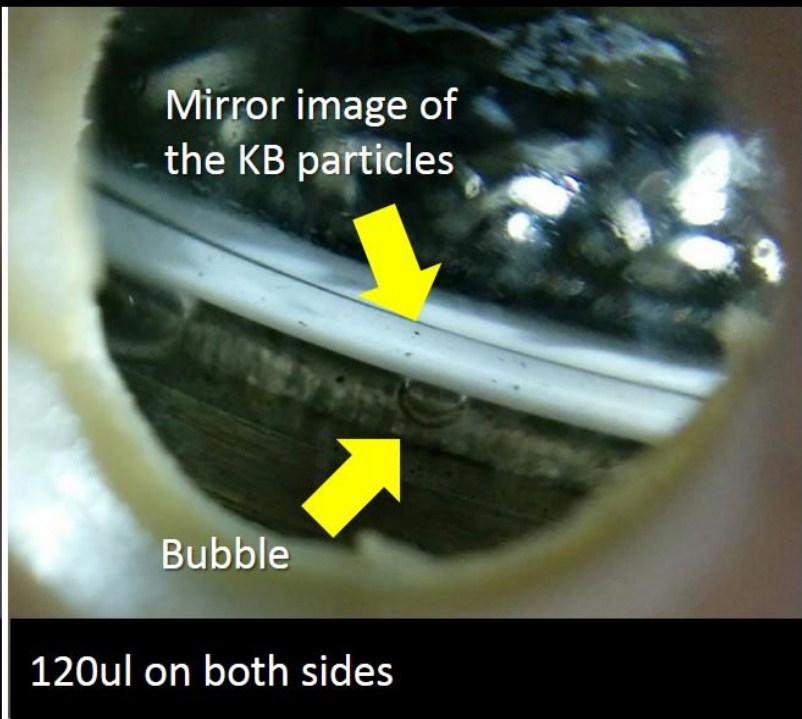

Figure S9. Photos of the cell components in an assembled OEMS cell with (a) 6o ul, (b) 100 ul and 120 ul electrolyte on both sides. The cell design incorporates a quartz spacer and a shell with observing holes to enable both excellent hematic sealing and convenient visual inspection of the cell components in the assembled state. 

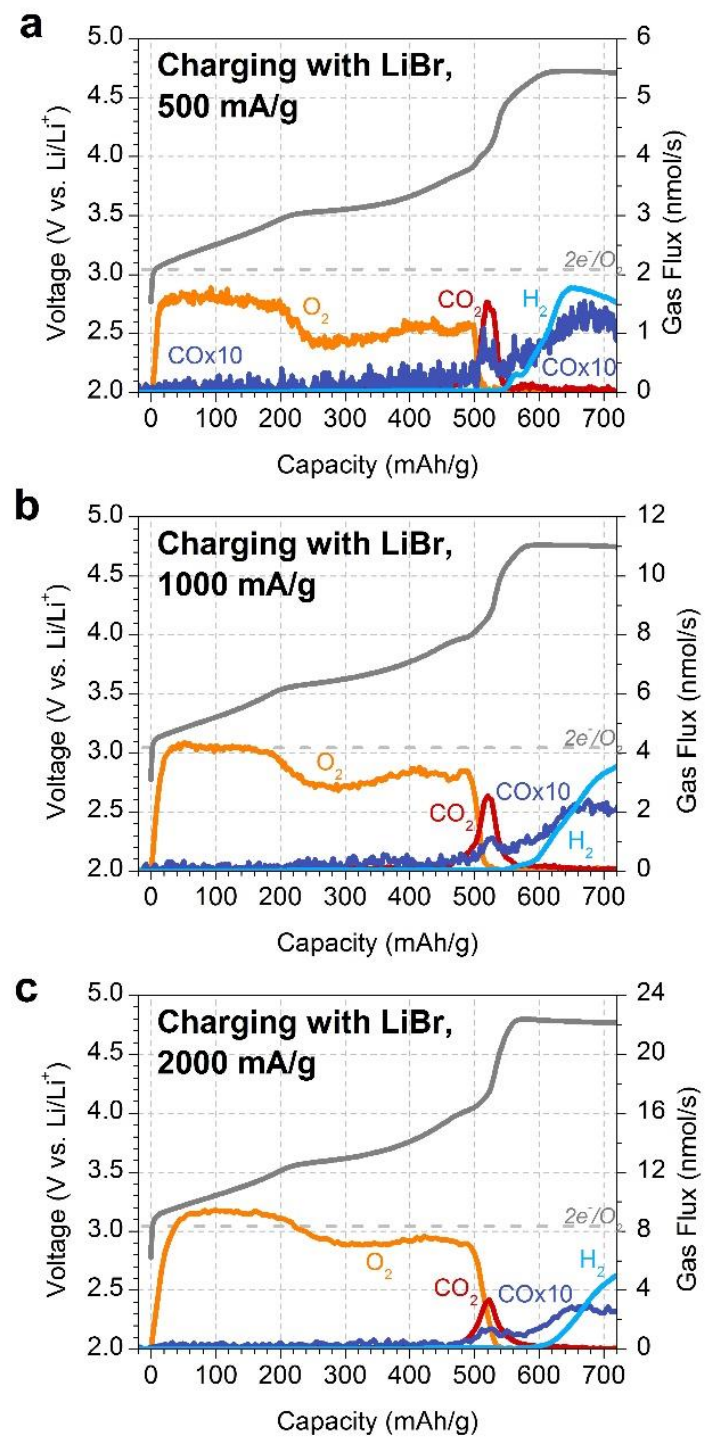

Figure Sio. Voltage and gas evolution profiles (without $\mathrm{H}_{2}$ magnification) during charging with $10 \mathrm{mM} \mathrm{LiBr}$ at (a) $500 \mathrm{~mA} / \mathrm{g}$, (b) $1000 \mathrm{~mA} / \mathrm{g}$ and (c) $2000 \mathrm{~mA} / \mathrm{g}$ after discharged to $500 \mathrm{mAh} / \mathrm{g}$ at $1000 \mathrm{~mA} / \mathrm{g}$. 

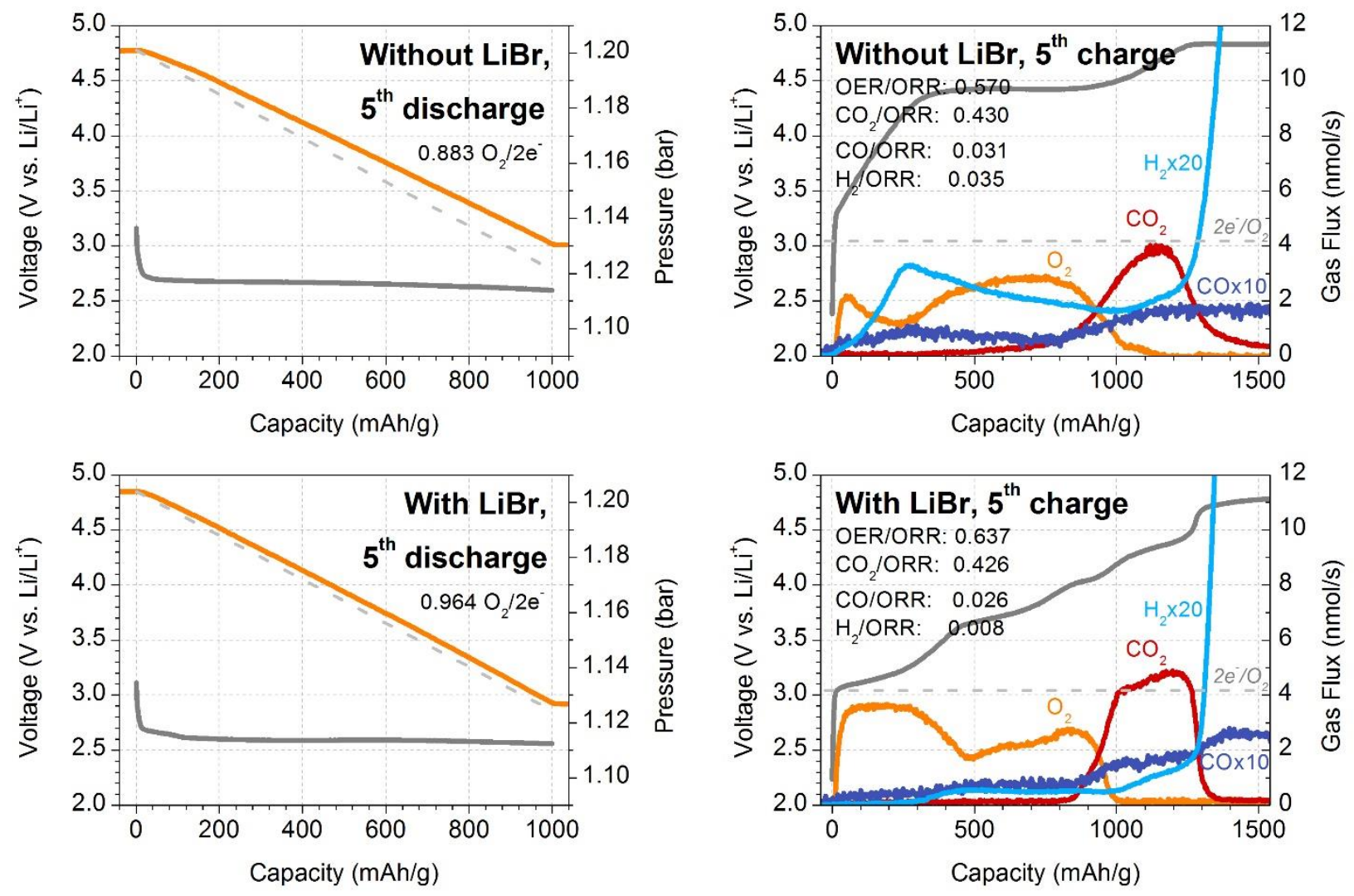

Figure S11. Voltage and gas evolution profiles of the $5^{\text {th }}$ charge without and with $10 \mathrm{mM} \mathrm{LiBr}$ after discharged to $1000 \mathrm{mAh} / \mathrm{g}$ at $1000 \mathrm{~mA} / \mathrm{g}$. 

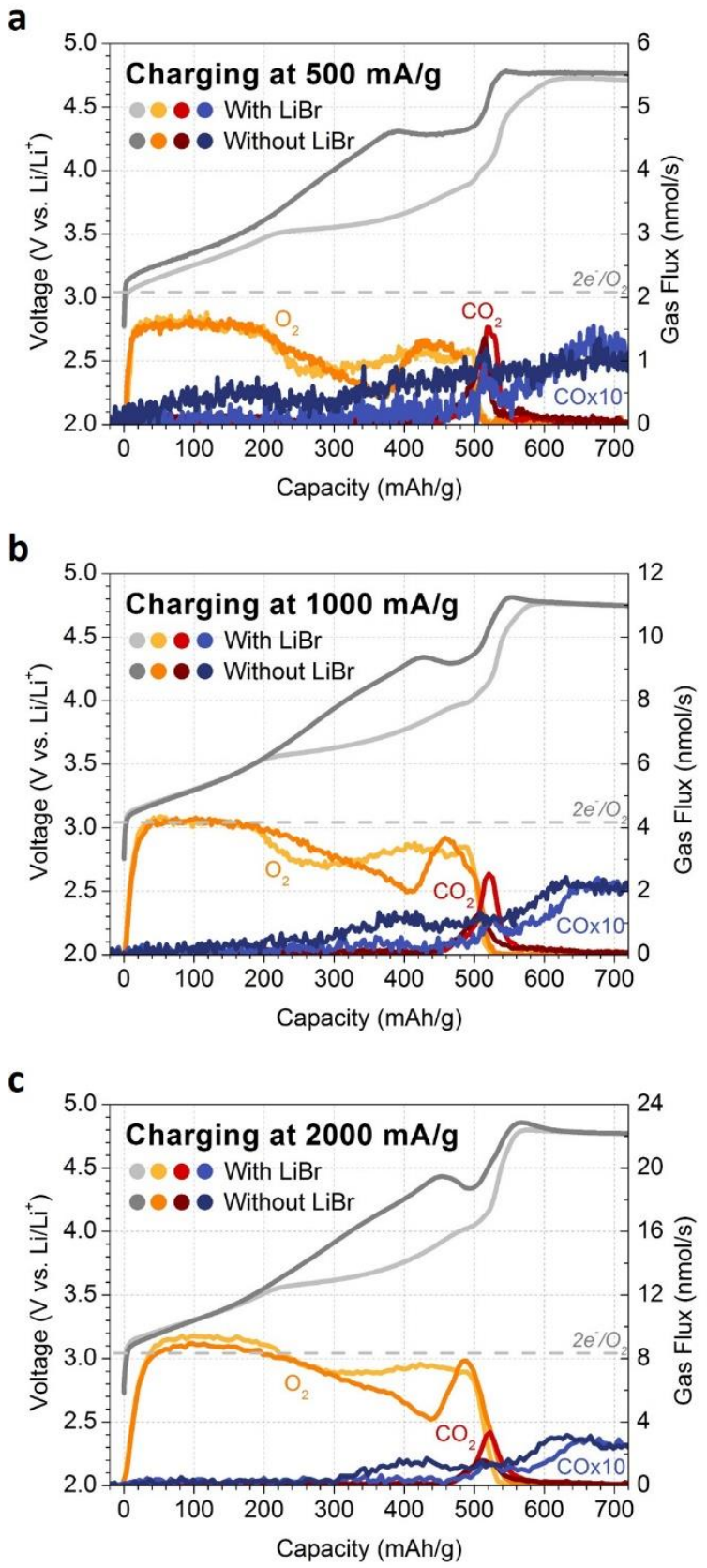

Figure S12. Voltage and gas evolution profiles during charging without $\mathrm{LiBr}$ at (a) $500 \mathrm{~mA} / \mathrm{g},(\mathrm{b})$ $1000 \mathrm{~mA} / \mathrm{g}$ and (c) $2000 \mathrm{~mA} / \mathrm{g}$ after discharged to $500 \mathrm{mAh} / \mathrm{g}$ at $1000 \mathrm{~mA} / \mathrm{g}$. The profiles of charging with $10 \mathrm{mM} \mathrm{LiBr}$ were overlaid for comparison. 


\section{Supplementary discussion 1:}

The capacity of oxygen reduction reaction is o.8 mAh. The full capacity of the redox mediator in this study (6oul of $10 \mathrm{mM} \mathrm{LiBr}$ ) is:

$10 \times 10^{-3}\left(\mathrm{~mol} \mathrm{Br}^{-} / \mathrm{L}\right) * 60^{*} 10^{-6}(\mathrm{~L}){ }^{*} 1$ mole $\left(\mathrm{e}^{-} / \mathrm{mol} \mathrm{Br}^{-}\right){ }^{*} 96485\left(\mathrm{C} / \mathrm{mole} \mathrm{e}^{-}\right){ }^{*} 1 / 3.6(\mathrm{mAh} / \mathrm{C})=$ $0.016 \mathrm{mAh}$, which is only about $2 \%$ of the capacity associated with oxygen reduction reaction.

\section{Supplementary discussion 2:}

Thermodynamic data used in the calculation of the reversible potential of Reaction 6(a):

\begin{tabular}{lll}
\hline Compound & $\Delta \boldsymbol{G}^{f}(\mathbf{k J} / \mathbf{m o l})$ & Reference \\
\hline $\mathrm{Li}_{2} \mathrm{CO}_{3}$ & -1132.1 & 1 \\
\hline $\mathrm{CO}_{2}$ & -394.4 & 1 \\
\hline $\mathrm{LiO}_{2}$ & -292.88 & 2 \\
\hline
\end{tabular}

The thermodynamic data of $\mathrm{LiO}_{2}$ at standard condition is not available in CRC handbook. Here we use the $\Delta \mathrm{G}$ value provided in ref 2 .

Accordingly, the Gibbs free energy of Reaction (6a) in the spontaneous direction (reduction):

$$
\Delta G=4 *(-1132.1 \mathrm{~kJ} / \mathrm{mol})-4 *(-394.4 \mathrm{~kJ} / \mathrm{mol})-2 *(-292.88 \mathrm{~kJ} / \mathrm{mol})=-2365.04 \mathrm{~kJ} / \mathrm{mol}
$$

The reversible potential at standard condition is:

$$
E^{0}=-\frac{\Delta G}{n F}=-\left(-2365.04 \frac{\mathrm{kJ}}{\mathrm{mol}}\right) * 1000 \div 6 \div 96485 \mathrm{C} / \mathrm{mol}=4.085 \mathrm{~V}
$$

In addition, the environment in the cell can be quite deviated from the standard condition. To estimate the effect of this deviation, we assume a $\mathrm{CO}_{2}$ partial pressure of 1 mbar and a $\mathrm{LiO}_{2}$ concentration of $1 \mu \mathrm{M}$, the reaction potential is estimated using the Nernst equation to be:

$E=E^{0}+\frac{R T}{z F} \ln \left[\mathrm{CO}_{2}\right]^{4}\left[\mathrm{LiO}_{2}\right]^{2}=4.085 \mathrm{~V}+\frac{8.314 \mathrm{~J} /(\mathrm{K} \cdot \mathrm{mol}) * 298.15 \mathrm{~K}}{6 * 96485 \mathrm{C} / \mathrm{mol}} \ln \left[10^{-3}\right]^{4}\left[10^{-6}\right]^{2}=3.849 \mathrm{~V}$

Thus, the range of the reversible potential of Reaction (6a) is estimated to be $3.85-4.09 \mathrm{~V}$.

\section{Supplementary discussion 3:}

The $\mathrm{O}_{2}$-evolution efficiency after $3.5 \mathrm{~V}$ is estimated using:

$$
\mathrm{O}_{2}-\text { Evolution Efficiency }=\frac{Q_{\text {Discharge }}}{Q_{3.5 \mathrm{~V} \text { to End of Charge }}} * \frac{O E R_{3.5 \mathrm{~V} \text { to End of Charge }}}{O R R}
$$

The definitions of the terms are:

$\mathrm{Q}_{\text {Discharge: }}$ the discharge capacity (i.e. $500 \mathrm{mAh} / \mathrm{g}$ );

$\mathrm{Q}_{3.5} \mathrm{~V}$ to End of Charge: the charge capacity between 3.5 V to the nominal end of charge (500 mAh/g);

ORR: the amount of $\mathrm{O}_{2}$ consumed during discharge;

$\mathrm{OER}_{3.5} \mathrm{~V}$ to End of Charge: the integrated amount of $\mathrm{O}_{2}$ evolved between $3.5 \mathrm{~V}$ to the nominal end of charge $(500 \mathrm{mAh} / \mathrm{g})$. 
$\mathrm{OER}_{3.5} \mathrm{~V}$ to End of Charge: the integrated amount of $\mathrm{O}_{2}$ evolved between $3.5 \mathrm{~V}$ to nominal end of charge (500 $\mathrm{mAh} / \mathrm{g})$.

\section{References:}

(1) Lide, D. R. CRC Handbook of Chemistry and Physics, 85th Edition. CRC Press: 2004

(2) Laoire, C. O.; Mukerjee, S.; Abraham, K. M.; Plichta, E. J.; Hendrickson, M. A. J. Phys. Chem. C 2010, 114, 9178-9186. 